Disponível em:

http://editora.unoesc.edu.br/index.php/race

RACE, Joaçaba, p. 73-104, Edição Especial, 2017

\title{
SUPREMACIA PEQUENO-BURGUESA NO CONSELHO MUNICIPAL DE DESENVOLVIMENTO ECONÔMICO DE JUIZ DE FORA (2010 A 2014)
}

Petty Bourgeoisie's supremacy in the Municipal Council of Economic Development of Juiz de Fora

Elcemir Paço Cunha

E-mail: paco.cunha@facc.ufjf.br

Doutor em Administração pela Universidade Federal de Minas Gerais; Mestre em Administração pela Universidade de Lavras; Professor adjunto na Universidade Federal de Juiz de Fora.

Endereço para contato: Campus Universitário, Martelos, 36030-330, Juiz de Fora, Minas Gerais, Brasil.

Leandro Theodoro Guedes

E-mail: ltheodoroguedes@yahoo.com Graduado em Administração pela Universidade Federal de Juiz de Fora.

Artigo recebido em 15 de agosto de 2017. Aceito em 13 de novembro de 2017. 
Resumo

O objetivo com o presente artigo foi explicitar a relação entre a burocracia e as classes sociais no interior das discussões do Conselho Municipal de Desenvolvimento Econômico de Juiz de Fora. Partiu-se de um entendimento que identifica a burocracia não como classe social, mas que funciona em meio ao conflito social. A partir da análise de dados econômicos e das atas entre 2010 e 2014, constatou-se que no Conselho se destaca a supremacia da pequena burguesia, que tem seus interesses alinhados às outras frações importantes do capital. O Conselho se mostra como um espaço de atuação permanente do capital, com os trabalhadores excluídos e os burocratas apassivados - eles próprios integrantes da pequena burguesia -, mostrando-se aliados ao capital sem propor ou questionar qualquer demanda, servindo como um meio para a efetivação de objetivos do capital.

Palavras-chave: Classes sociais. Pequena burguesia. Burocracia. Conselho Municipal.

\section{Abstract}

The objective of this paper was to show the relationship between bureaucracy and social classes in the Municipal Council of Economic Development of Juiz de Fora. The background sustain bureaucracy as not a social class although it has function within social conflict. From economic data and minutes (between 2010 and 201) analysis, it was found the petty bourgeoisie's supremacy and its interests lined up with other fractions of capital. The Council is a space of permanent action of capital in which works are excluded. The bureaucrats are tender - themselves as components of petty bourgeoisie - in their alliance with capital without proposing or questioning any demand. In fact, the Council serves to the effectuation of capital aims.

Keywords: Social classes. Petty bourgeoisie. Bureaucracy. Municipal Council.

\section{INTRODUÇÃO}

O objetivo com o presente artigo é demonstrar a relação entre a burocracia municipal de Juiz de Fora e as classes sociais por mediação do exame da configuração e das decisões do Conselho Municipal de Desenvolvimento Econômico (CMDE) de Juiz de Fora. O Conselho em tela foi regulamentado em 07 de maio de 2010 pelos Decretos n. 10.234, de 07 de maio de 2010, e n. 09.704, de 01 de dezembro de 2008, com competência para estudar, sugerir, emitir pareceres e promover políticas e medidas atinentes ao desenvolvimento econômico. Reconhecido nacionalmente como parte do “espírito republicano” e da experiência dos últimos 30 anos de ampliação da participação da chamada “sociedade civil” nas matérias públicas, o Conselho (como 
exemplar de seu tipo) ligado diretamente ao assunto econômico possibilita compreender as expressões das contradições sociais.

Em termos fundamentais, tais contradições estão ligadas às classes sociais as quais são, com grande frequência, ignoradas da existência pelas análises comuns ao "campo de públicas". Nesse sentido, são poucos os estudos que exploram tais contradições, a administração pública e a burocracia de Estado (GURGEL; JUSTEN, 2013; SOUZA FILHO; GURGEL, 2016; PAÇO CUNHA, 2016, REZENDE, 2016). Privilegiando uma conceituação apriorística sustentada no tripé Estado, mercado e sociedade civil, as análises no "campo de públicas” tendem a perder da realidade as contradições que ajudam a explicar seu próprio movimento. Seguindo por esse caminho, essa conceituação apriorística e abstrata não apreende a desigualdade dos interesses materiais e tende a sacrificar a existência das contradições econômicas no altar da igualdade abstrata da cidadania.

A compreensão da dinâmica conflitiva em relação ao Conselho se justifica em razão de suas decisões implicarem aplicação de recursos públicos e contribuição para elaboração e efetivação de políticas públicas. No que se refere ao aspecto econômico do Conselho, isso ganha maior peso, pois as consequências atingem a dinâmica social, econômica e política local.

Para realizar o objetivo, adotaram-se dois recursos básicos. No primeiro, foram levantados dados econômicos e fiscais sobre o Município para realizar uma aproximação a respeito das classes existentes. No segundo, analisou-se a composição e as atas do Conselho indicado, procurando revelar as tendências internas das decisões, alianças, participações e omissões. A decisão por esse Conselho em particular ocorreu, como adiantado, em razão de o caráter econômico e vinculação a fundo municipal específico serem potencialmente marcados pelo conflito de interesses entre as classes e frações de classes na cidade. Já a escolha dessa alternativa operacional de pesquisa deve-se, em parte, ao fato de que as atas registram orientações, diagnósticos, decisões e utilização de recursos públicos. Adicionalmente, a escolha se deve também à impossibilidade de aplicar questionário semiaberto aos funcionários da Prefeitura de Juiz de Fora - a despeito das inúmeras tentativas com as autoridades por mais de um ano. Essa obstrução do interesse científico já alude para a dificuldade de se estudar o setor público no Brasil. Nesse sentido, baseando-se apenas nas atas, esta pesquisa pode ser considerada qualitativa (DEMO, 1985). Operacionalmente, as atas foram acessadas no site da Prefeitura de Juiz de Fora no dia 14 de abril de 2016 e salvas em computador e hospedadas também em nuvem. Um novo acesso ao site em julho de 2017 revelou que a medida foi acertada uma vez que as atas já não se encontram 
disponíveis ao público. ${ }^{11}$ Foram analisadas 27 atas do Conselho Municipal de Desenvolvimento Econômico (CMDE) referentes às reuniões entre 2010 e 2014. O período foi escolhido em razão da disponibilidade das atas à época de sua consulta. Essas atas passaram por leituras exaustivas pelos pesquisadores com compilação de dados de frequências de participação e análises qualitativas que apontam para a articulação interna ao Conselho e para o cui bono das tendências centrais de suas decisões. No conjunto, esses elementos contribuíram para determinar a procedência das hipóteses de trabalho indicadas adiante.

De tal maneira, o restante do trabalho está dividido em cinco partes, além da presente introdução. Nas duas partes que seguem, apresentam-se discussões em relação à burocracia de Estado e às classes sociais de maneira que se apreendem hipóteses centrais de trabalho. Nas outras duas partes subsequentes, apresentam-se os dados da pesquisa e a discussão dos resultados. E, por fim, encontram-se as considerações finais do presente artigo.

\section{BUROCRACIA ESTATAL COMO POSIÇÃO DISTINTA}

O desenvolvimento do capitalismo ao longo dos séculos XX e XXI produziu inúmeras modificações em sua dinâmica, tanto no aspecto imediatamente econômico quanto no político e em suas reciprocidades. Esse conjunto de movimentos implicou alterações no quadro das composições das classes sociais, produzindo inúmeros debates em relação à alegada sociedade "pós-capitalista”, centrada agora no conhecimento e com uma “nova classe” dominante (cf. Galbraith (1973) e Mészáros (2011)).

Umas das linhas muito férteis desse debate se encontra precisamente nesse último ponto. Com a transição do capitalismo entre os séculos XIX e XX, duas movimentações produziram o pano de fundo objetivo para a elaboração de uma "teoria dos gestores”, isto é, de que uma “nova classe” surgia na esfera econômica e na do Estado, tornando-se a classe dominante em lugar do capital: o processo de consolidação das sociedades anônimas e a decorrente separação entre propriedade e gestão do capital; e a revolução na Rússia, alçando a posição da burocracia do Estado à condição política relativamente incomum. Esses dois movimentos da realidade, tomados ou não de modo combinado, serviram de base para que um conjunto consideravelmente vasto de

\footnotetext{
${ }^{1}$ Por essa razão as referências bibliográficas que registram as atas contêm ligação com os arquivos originais agora hospedados em nuvem da própria pesquisa, garantindo transparência e rigor para as análises adiante.
} 
autores sustentasse que os "gestores” se consolidaram como a nova classe dominante ao longo do século XX.

Para o caso da primeira movimentação, ergueu-se uma propositura de um “capitalismo gerencial”, regido pelos gestores das grandes corporações e pelos gestores no interior do Estado. O impulso de planificação da economia, as estratégias desenvolvimentistas e as políticas keynesianas acresceram-se sobre a separação entre propriedade e gestão de modo que um maior protagonismo do poder executivo foi capturado como índice que confirmava uma nova configuração de classe. No caso russo, a centralização das decisões econômicas em uma estrutura burocrática levou um contingente de intelectuais à conclusão de que não foi o caso de uma revolução dos trabalhadores, mas uma revolução dos gestores.

Por derivação dessa última tendência, construiu-se um considerável volume de páginas para afirmar a burocracia do Estado como nova e dominante classe social, inclusive para o Ocidente. Bernardo (1985), por exemplo, confessa a derivação de suas análises a partir do caso russo. O mesmo não ocorre com Bresser-Pereira (1982), sustentada, inclusive, a tese de que o próprio capitalismo havia sido superado por um modo de produção tecnoburocrático, isto é, sob domínio dos gestores da burocracia pública e privada. As questões problemáticas foram apontadas por Hirata (1980) (cf. Belluzzo e Lima (1978)), sobretudo a impropriedade de uma extrapolação do caso russo. As reticências da autora são corretas, uma vez que a própria realidade histórica se encarrega de demonstrar que segue o capitalismo e que não prevaleceu a hipótese de Rizzi (1983), original de 1939, de um domínio absoluto da burocracia como classe em todos os lugares do mundo. No entanto, as polêmicas cortam todo o século XX e apontam para certo exagero na determinação da burocracia de Estado como classe em si, mesmo para o caso russo (cf. Mandel (1985) e Mészáros (2011)).

Mas com isso não se pode ignorar que tais gestores da esfera do Estado ocupam posições estratégicas em termos de informação e autoridade (MÉSZÁROS, 2011). A função que desempenham, em razão de certa divisão do trabalho, produz reciprocidades importantes com as condições econômico-materiais, sobretudo com respeito à burocracia estatal como a dimensão que se analisa mais de perto:

A coisa apreende-se do modo mais fácil do ponto de vista da divisão do trabalho. A sociedade produz certas funções comuns, que não pode dispensar. As pessoas nomeadas para isso formam um novo ramo da divisão do trabalho no interior da sociedade. Adquirem com isso interesses particulares também face aos 
seus mandantes, autonomizam-se face a eles e - eis o Estado. E então passa-se de modo semelhante ao que [se passa] com o comércio de mercadorias e, mais tarde, com o comércio de dinheiro: o novo poder autônomo tem, com efeito, grosso modo, que seguir o movimento da produção, mas reage também - por causa da autonomia relativa que lhe é inerente, isto é, que lhe foi uma vez conferida e que gradualmente se continua a desenvolver - de novo sobre as condições e o curso da produção. E uma ação recíproca de duas forças desiguais: o movimento econômico, de um lado, e o novo poder político, que aspira o mais possível à autonomia e que, uma vez estabelecido, fica dotado também de um movimento próprio; o movimento econômico, grosso modo, vem ao de cima, mas tem de sofrer também uma retroação do movimento político por ele próprio criado e dotado de relativa autonomia: do movimento, por um lado, do poder do Estado, por outro lado, do da oposição criada ao mesmo tempo que ele. (MARX; ENGELS, 2010, p. 59-60).

Disso parece resultar que a burocracia de Estado assume, por princípio, uma diferente posição diante dos conflitos que são postos no interior das condições econômico-materiais, mesmo que não assuma o caráter de classe em si. Assim, elege-se a primeira hipótese de trabalho a ser enfrentada na pesquisa: os ocupantes das presidências do Conselho assumem uma posição distinta das classes existentes. Essa posição ficará mais clara com a discussão subsequente em que se explicita uma caracterização da burocracia municipal e das classes fundamentais na Cidade de Juiz de Fora a partir de dados secundários.

\section{BUROCRACIA MUNICIPAL E CLASSES SOCIAIS FUNDAMENTAIS}

Antes de mais nada, é preciso dizer que a caracterização classificatória a seguir não é exaustiva. O problema das classes sociais e de suas frações impõe a dificuldade de se rastrearem todas as suas trilhas e conexões, correndo o risco de se perder em detalhes muito específicos.

Em razão disso, apresenta-se uma diferenciação em termos de posição social em relação a lucro e salário que é determinada não por acesso a "recursos do mercado”, mas primariamente pela distribuição dos meios de produção que, por sua vez, implica a distribuição da riqueza produzida (MARX, 2011). Desconsideraram os ganhos por renda territorial, salários e lucros vinculados à produção agrícola por 
sugestão dos próprios dados secundários extraídos do IBGE (2017) sobre o Município de Juiz de Fora. O valor adicionado bruto da agropecuária, em 2014, foi de R\$ 43.171.000,00, enquanto o da indústria foi de $\mathrm{R} \$ 2.702 .832 .000,00$ e o dos serviços, de R 7.369.350.000,00. Nesse sentido, o corte das análises tangenciou o contexto urbano. Com efeito, uma análise da Cidade de Juiz de Fora permite a apreensão de um quadro geral sobre as classes sociais e a burocracia municipal, como segue.

Capital. A classe capitalista se divide no geral entre três frações básicas (MARX, 2017): o capital produtivo ligado à inversão de capitais na produção de mercadorias donde extrai lucro produtivo; o capital financeiro que opera no mercado extraindo lucro financeiro de capital a juros, mercado de ações e operações bancárias; e o capital comercial que, como o nome sugere, extrai lucro das operações de circulação mercantil de bens e serviços.

Particularmente, na Cidade de Juiz de Fora, o capital produtivo se materializa pela instalação de multinacionais dos setores automotivo e metalúrgico, além de outros setores dominados por capital nacional de médio porte, como fábricas de recipientes plásticos e empresas de transporte, e de pequeno porte, como as indústrias de vestuário. O capital financeiro segue a tendência nacional e é pouco desenvolvido localmente, pois funciona por meio de agências de bancos nacionais e internacionais. Esse aspecto é diferenciador entre os planos municipal e estatal, pois os problemas da financeirização da dívida pública, por exemplo, são de dimensões inteiramente diferentes, e as instituições bancárias na cidade estão mais ligadas aos serviços bancários operacionais e de financiamento patrimonial, isto é, localmente não se processam as operações de mercado de ações. Ainda assim, segundo o IBGE (2017), registrou-se R \$ 5.134.169.903,00 em operações de crédito no ano 2016, variando pouco em relação aos anos anteriores. Então, o destaque, como demonstra o PIB mencionado, fica com o capital comercial, mais numeroso e desenvolvido numa cidade que vem servindo de entreposto de distribuição entre Rio de Janeiro, Belo Horizonte e São Paulo. O cenário é dominado, por um lado, por grandes centros de distribuição e, por outro, por muitos grupos de varejo e atacado no ramo alimentício, como supermercados.

Alguns dados ajudam a confirmar essa tendência de destaque para o capital comercial.

O IBGE (Gráfico 1) acusa uma vantagem histórica de participação do setor de serviços no PIB do Município. Há uma tendência bastante estável de ser sempre mais que o dobro da participação industrial. 


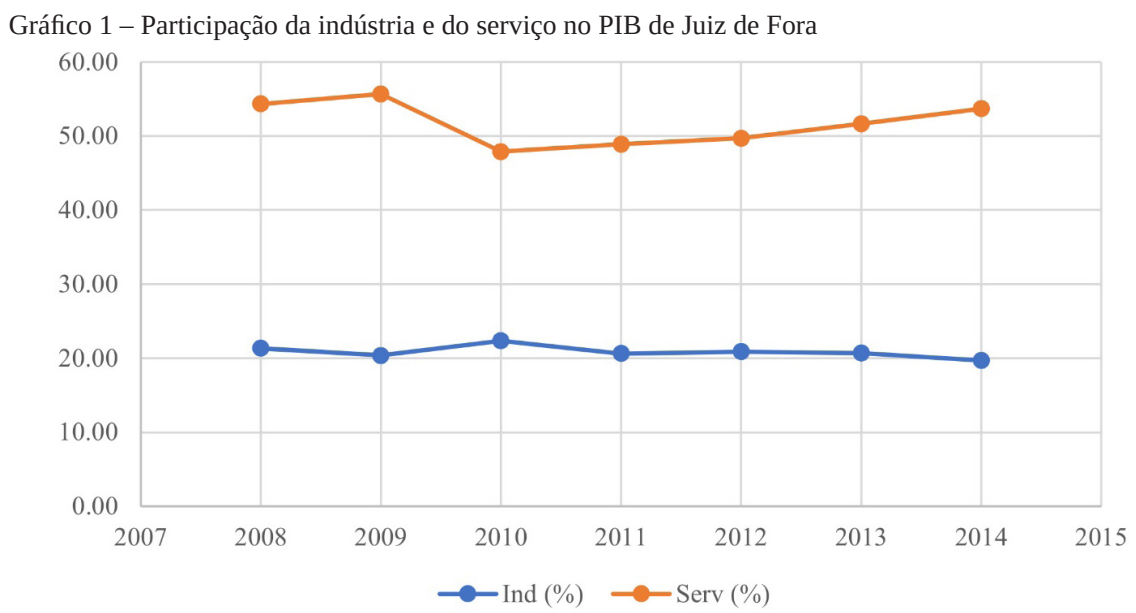

Fonte: elaborado pelos autores a partir dos dados do IBGE (2017).

Outro dado importante a ser acrescido diz respeito às receitas municipais. Na comparação entre ISSQN e ICMS (Gráfico 2), vê-se que a diferença em termos percentuais é relativamente pequena entre as participações nas receitas correntes. Se for considerado que a contribuição industrial está incluída no ICMS conjuntamente às operações comerciais típicas, pode-se supor, considerando-se a diferença de participação no PIB do Município, que prevalecem de fato as operações do capital comercial em detrimento do produtivo.

Gráfico 2 - Participação do ISSQN e ICMS nas receitas correntes

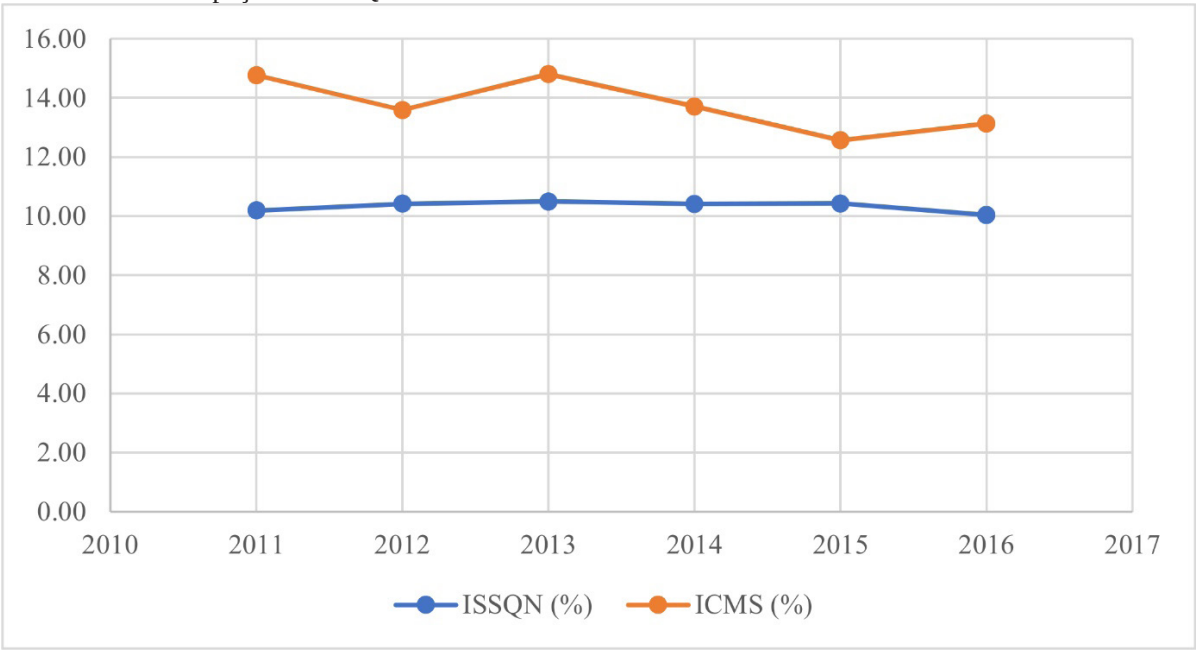

Fonte: elaborado pelos autores a partir dos dados da Prefeitura Municipal de Juiz de Fora (2017). 
Isso sustenta a segunda hipótese de trabalho: que o capital comercial tem maior peso econômico no Município e, por essa razão, sua atuação como fração de classe pode ganhar protagonismo, isto é, há uma supremacia do capital comercial.

Trabalho. A classe trabalhadora é bem mais multifacetada. Mas, para efeito de análise, não é inadequado considerar uma divisão de acordo com o capital com o qual se relaciona. Assim, tem-se o trabalho produtivo, o financeiro e o comercial. O movimento trabalhista em Juiz de Fora guarda históricas atividades grevistas no século XIX, por parte dos trabalhadores do comércio (OLIVEIRA, 2010), e ao tempo do desenvolvimento da indústria têxtil (ANDRADE, 1987). Em mais da metade do século XX e até o momento do século XXI, no entanto, essa atividade tem sido mais presente no setor dos transportes. No caso, trata-se de um setor de movimentação urbana principalmente da força de trabalho e de estudantes. De maneira que esse trabalho pode ser compreendido em relação ao capital comercial. Além disso, pelo próprio ritmo da atividade econômica antes ilustrada, é seguro supor que o maior número de trabalhadores se relaciona com o capital comercial e não com o produtivo, seguindo as tendências mundiais de ampliação do emprego no setor de serviços. A classe trabalhadora possui inúmeras representações de classe, e essa fragmentação sindical pesa em sua articulação na cidade. Nesse sentido, daqui se extrai a terceira hipótese de trabalho: os trabalhadores empregados pelo capital comercial atuam ativamente no interior do Conselho.

Pequena burguesia. Chama a atenção o quantitativo de pequenos e médios comerciantes. Como fração mais frágil associada à obtenção de lucro mercantil se comparada ao grande capital comercial, essa pequena burguesia é protuberante por sua atuação conjunta na cidade por meio de seus inúmeros órgãos de representação, como CDL e Abrasel, e outros órgãos de caráter técnico, como o Sebrae e o Senac. Nessa pequena burguesia incluem-se os pequenos proprietários de todos os tipos, como o microempreendedor individual com negócio próprio. Excluem-se aqueles indivíduos com registro dessa natureza, mas que vendem sua força de trabalho para os tipos de capital antes indicados e, dessa maneira, caem na categoria trabalhador produtivo, financeiro ou comercial.

Em termos econômicos, não foi possível fazer distinção entre a pequena burguesia e o capital comercial em relação à participação no PIB e nas Receitas Correntes. Certamente elas são a maioria das 21.851 unidades empresariais registradas pelo IBGE em 2015. Em razão disso, é possível estabelecer uma quarta hipótese de trabalho: a pequena burguesia divide a supremacia com o capital comercial. 
Um aspecto importante é a caracterização a seguir dessa pequena burguesia e que pode ajudar a explicar suas possíveis alianças:

[Trata-se da] classe do pequeno comércio e dos lojistas [...] A sua posição intermédia entre a classe dos grandes capitalistas, comerciantes e manufatureiros, a burguesia, propriamente dita, e a classe proletária ou industrial determina o seu carácter. Aspirando à posição da primeira, o menor golpe adverso da fortuna deita abaixo os indivíduos desta classe para as fileiras da segunda [...] [A pequena burguesia é] eternamente sacudida entre a esperança de entrar nas fileiras da classe mais rica e o medo de ser reduzida à condição de proletários ou mesmo de pobres; entre a esperança de promover os seus interesses, conquistando uma parte da direção dos negócios públicos, e o receio de, por uma oposição intempestiva, desencadear a ira de um governo que dispõe da sua própria existência, porque tem o poder de retirar os seus melhores fregueses; possuidora de pequenos meios, cuja insegurança de posse está na razão inversa do seu montante. (ENGELS, 2010, p. 9-10).

Essa posição de classe cria todo tipo de ambiguidade para os indivíduos, dado que varia bastante as condições econômicas no interior de uma mesma classe. Isso se agrava quando se considera o desenvolvimento de uma nova pequena burguesia. Essa nova configuração da pequena burguesia inclui as atividades profissionais de indivíduos tipicamente não proprietários (embora possam ter negócios próprios), como administradores, advogados, engenheiros, professores, etc. São, no geral, trabalhadores assalariados, mas em razão de escolaridade, remuneração e função social tendem a coadunar com as posições burguesas e pequeno-burguesas e não caem diretamente na categoria de trabalhadores no sentido anterior (POULANTZAS, 1978, p. 221-312). Trata-se de um aspecto polêmico, mas aqui vale a mesma ressalva sobre a pequena burguesia, qual seja, de que a variação das condições econômicas coloca os indivíduos concretos em posições muito desiguais de classe. Um tributarista, por exemplo, não se compara linearmente com um professor secundarista, nem em termos de renda, função ou inclinações ideológicas. Mas se considera que a classificação não é exaustiva e serve apenas como norteadora.

Burocracia. Enquanto tais, os funcionários públicos da esfera estatal em todos os níveis não formam uma classe fundamental em si, mas uma categoria social específica (POULANTZAS, 1978, p. 201). Podem desenvolver, como se viu antes, interesse próprio (MARX; ENGELS, 2010) e atuação conjunta e alianças (POULANT- 
ZAS, 1978), o que produziu a impressão de se tratar não somente de uma classe à parte do capital e do trabalho, mas, também, em razão dos elementos apontados antes, por se tratar de uma nova classe dominante. A respeito da composição, Poulantzas (1978, p. 202) assevera que na cúpula ou "vértice” da burocracia tendem a ocupar os cargos indivíduos provenientes da classe do capital ou burguesia, enquanto que nos níveis intermediários e inferiores, ocupam posições os indivíduos advindos da pequena burguesia e da nova pequena burguesia. Para o caso concreto sob investigação, vale destacar que interessam mais as posições principais nas presidências do Conselho (o que pressupõe a presidência da Secretaria de Desenvolvimento Econômico) para efeito de análise dessa aliança e não todo o conjunto da burocracia municipal. Nesse caso é de se supor que os indivíduos que ocupam o "vértice" da burocracia tenderiam a se aliar aos capitais (produtivo, financeiro ou comercial), formando, assim, a quinta e última hipótese de trabalho: os presidentes do Conselho se aliam à supremacia comercial ou à supremacia dividida com a pequena burguesia.

Com base nas questões levantadas, sugerem-se cinco hipóteses de trabalho assim resumidas:

H1. Os presidentes do Conselho assumem uma posição distinta diante das classes existentes.

H2. Há supremacia do capital comercial.

H3. Os trabalhadores empregados pelo capital comercial atuam ativamente em conflito no interior do Conselho.

H4. A pequena burguesia divide a supremacia com o capital comercial.

H5. Os presidentes do Conselho se aliam à supremacia comercial ou à supremacia dividida com a pequena burguesia.

A seguir analisa-se mais detidamente o Conselho, procurando revelar a relação entre a burocracia municipal e as classes sociais.

\section{BUROCRACIA E CLASSES NO CONSELHO MUNICIPAL DE DESENVOLVIMENTO ECONÔMICO}

Analisou-se o Conselho Municipal de Desenvolvimento Econômico a partir das atas encontradas no site oficial da Prefeitura de Juiz de Fora, distribuídas entre os anos 2010, em que o Conselho iniciou suas atividades, e 2014. Procurou-se inquirir, nessas atas, como a burocracia municipal se comporta em relação às demandas do capital e do trabalho, demarcando elementos que possam indicar de maneira mais 
precisa as posições da burocracia mediante a luta de classes. Entre as competências desse Conselho destacam-se:

I - estudar e sugerir medidas que visem à expansão das atividades de desenvolvimento econômico, comercial, turística e de ciência e tecnologia do Município; [...] III - aconselhar os setores competentes da Prefeitura de Juiz de Fora no desenvolvimento de programas de fomento às atividades de política de desenvolvimento econômico sustentado, comercial, turística e de ciência e tecnologia; [...] VI - promover medidas, em articulação com os diferentes órgãos governamentais ou de iniciativa privada, visando o aproveitamento de incentivos ou recursos destinados ao desenvolvimento econômico sustentado, do comércio, do turismo e da ciência e tecnologia do Município; VII - promover, anualmente, o Fórum Municipal da Micro e Pequena Empresa com a finalidade de mobilização dos diversos segmentos em prol do aprimoramento das políticas públicas às micro, pequenas empresas e empreendedores individuais. (JUIZ DE FORA, 2010a).

Do exposto, apresenta-se de forma suficientemente clara a proximidade do Conselho com alguns setores do capital local, especialmente o comercial e a pequena burguesia. Tal relação de proximidade também pode ser comprovada em outros lugares, como na lei que arregimenta o Conselho. Na seção dedicada aos componentes não é possível encontrar qualquer organização de representação dos trabalhadores, sejam eles sindicatos, sejam movimentos sociais:

Art. $2^{\circ} \mathrm{O}$ Conselho de Desenvolvimento Econômico será presidido pelo Secretário de Planejamento e Desenvolvimento Econômico e composto por representantes dos seguintes órgãos e entidades: I - Secretaria de Fazenda - SF; II - Secretaria de Planejamento e Desenvolvimento Econômico - SPDE; III - Universidade Federal de Juiz de Fora; IV - Associação Comercial de Juiz de Fora; V - Centro Industrial de Juiz de Fora; VI - Sindicato dos Hotéis, Restaurantes, Bares e Similares de Juiz de Fora; VII - Sindicato do Comércio Varejista; VIII - Agência de Desenvolvimento de Juiz de Fora e Região; IX - Centro Nacional de Pesquisa de Gado de Leite - EMBRAPA; X - Câmara de Dirigentes Lojistas - CDL; XI - Federação das Indústrias do Estado de Minas Gerais - FIEMG; XII - Associação Brasileira de Restaurantes e Empresas de Entretenimento - ABRASEL; XIII - Serviço de Apoio às Micro e Pequenas Empresas de Mi- 
nas Gerais - SEBRAE; XIV - Juiz de Fora e Região Convention \& Visitors Bureau. (JUIZ DE FORA, 2010a).

Nas atas, constam também algumas adições de novos conselheiros aprovados, como se observa a seguir:

recebeu solicitações oficiais por parte da $\mathrm{ABAV}^{2}$ e das Secretarias de Atividades Urbanas, Agropecuária e Abastecimento e da Agência de Gestão Ambiental de Juiz de Fora para participação das mesmas no Conselho Municipal de Desenvolvimento Econômico. As solicitações foram colocadas para votação sendo aprovadas por unanimidade. (CONSELHO MUNICIPAL DE DESENVOLVIMENTO ECONÔMICO, 2010c).

Considerando que os elementos citados não são diretamente ligados aos trabalhadores, verifica-se que, em contraponto a isso, a solicitação de participação feita por um sindicato de trabalhadores sequer foi levada à discussão. Esse fato ocorreu em uma reunião em outubro de 2010, de acordo com o que segue:

\begin{abstract}
a participação de representantes do Sindicato dos Trabalhadores no Conselho Municipal de Desenvolvimento Econômico, para que haja maior interatividade entre as partes, quais sejam: os trabalhadores e o empresariado. O [Visitante 1] enfatizou que esta é uma reivindicação antiga do Sindicato. A seguir, a [Visitante 2] e o [Visitante 3] informaram sobre os programas de qualificação profissional desenvolvidos pela Secretaria de Assistência Social. (CONSELHO MUNICIPAL DE DESENVOLVIMENTO ECONÔMICO, 2010c).
\end{abstract}

O grande significado dessa fala é que, depois de feita, não foi sequer comentada pelos outros representantes (de tal modo que a fala imediatamente posterior ao sindicalista trata de outro assunto completamente diferente), e mesmo que o espaço para os sindicatos tenha sido cedido, não se encontrou, em nenhuma outra ata, a fala de instâncias representativas dos trabalhadores, ou mesmo sua presença. Essa questão já aponta para alguma orientação básica do Conselho, o que se confirma pela identificação da presidência.

\footnotetext{
${ }^{2}$ Associação Brasileira de Agências de Viagens.
} 
Durante o período analisado, houve dois presidentes e um vice-presidente. Pelos registros disponíveis no Currículo Lattes, um dos presidentes possui três direções de atividades: secretário de duas secretarias ligadas ao desenvolvimento econômico (2009-2016), consultor de empresas (com empresa registrada) na área financeira e professor universitário de faculdade particular. Por essas características, é possível caracterizá-lo como indivíduo incluso na nova pequena burguesia. O segundo presidente do Conselho, conforme informa a Prefeitura, é empresário e ex-presidente da Associação Brasileira de Bares e Restaurantes da Zona da Mata. Essas informações permitem incluí-lo na típica pequena burguesia. Já o vice-presidente no período, segundo a Prefeitura e o Currículo Lattes, é um servidor público, professor universitário de instituições particulares e consultor em gestão empresarial com empresa registrada. Nesse sentido, é possível incluí-lo também entre indivíduos da nova pequena burguesia. Vê-se, pela composição da burocracia municipal na presidência do Conselho, que a classe dirigente dista do grande capital e dos trabalhadores.

Além dessa orientação básica e da composição da presidência, com base nas atas foi possível chegar às frequências de participação nas reuniões do Conselho (Tabela 1). A partir das 27 reuniões realizadas no período, aglomerou-se essa participação em três categorias: vinculados à burocracia municipal, cuja presença de seus membros representou 36,7\% do total, ao capital (50,2\%) e aos visitantes (13,1\%).

\begin{tabular}{lrr}
\hline \multicolumn{1}{c}{ Órgão } & $\begin{array}{c}\text { \% de par- } \\
\text { ticipação } \\
\text { em relação } \\
\text { ao total de } \\
\text { reuniões }\end{array}$ \\
\hline $\begin{array}{l}\text { Presidente (Burocracia Municipal) } \\
\begin{array}{l}\text { Associação Brasileira de Restaurantes e Empresas de Entretenimento (Abrasel) } \\
\text { (Capital) }\end{array}\end{array}$ & 27 & 100.00 \\
$\begin{array}{l}\text { Centro Industrial de Juiz de Fora (Capital) } \\
\text { Conselho Regional de Economia (Corecon) }\end{array}$ & 17 & 70.37 \\
$\begin{array}{l}\text { Secretaria de Planejamento e Desenvolvimento Econômico (SPDE) } \\
\text { cia Municipal) }\end{array}$ & 17 & 62.96 \\
\hline
\end{tabular}

\footnotetext{
${ }^{3}$ Esse órgão não se enquadra diretamente nem ao empresariado nem à burocracia, embora a orientação da participação deixe poucas dúvidas sobre o alinhamento à nova pequena burguesia. Ainda assim, optou-se por deixá-lo neutro.

${ }^{4}$ Como presidente e vice-presidente do Conselho faziam parte da Secretaria de Planejamento e Desenvolvimento Econômico (SPDE), e, por diversas vezes, ambos participaram das reuniões, optou-se por vincular a participação do vice-presidente à SPDE.
} 


\begin{tabular}{|c|c|c|}
\hline Órgão & Freq. & $\begin{array}{l}\text { \% de par- } \\
\text { ticipação } \\
\text { em relação } \\
\text { ao total de } \\
\text { reuniões }\end{array}$ \\
\hline $\begin{array}{l}\text { Serviço de Apoio às Micro e Pequenas Empresas de Minas Gerais (Sebrae) } \\
\text { (Capital) }\end{array}$ & 15 & 55.56 \\
\hline Agência de Desenvolvimento de Juiz de Fora e Região (ADJF) (Capital) & 14 & 51.85 \\
\hline Câmara de Dirigentes Lojistas (CDL) (Capital) & 13 & 48.15 \\
\hline Secretaria de Fazenda (SF) (Burocracia Municipal) & 13 & 48.15 \\
\hline Juiz de Fora e Região Convention \& Visitors Bureau (Capital) & 12 & 44.44 \\
\hline Centro Nacional de Pesquisa de Gado de Leite (Embrapa) ${ }^{5}$ & 11 & 40.74 \\
\hline Secretaria de Agropecuária e Abastecimento (SAA) (Burocracia Municipal) & 9 & 33.33 \\
\hline Universidade Federal de Juiz de Fora (UFJF) ${ }^{6}$ & 7 & 25.93 \\
\hline Associação Brasileira das Agências de Viagens (ABAV) (Capital) & 7 & 25.93 \\
\hline Sindicato dos Hotéis, Restaurantes, Bares e Similares de Juiz de Fora (Capital) & 6 & 22.22 \\
\hline Serviço Nacional de Aprendizagem Comercial (Senac) ${ }^{7}$ (Capital) & 5 & 18.52 \\
\hline Sindicato do Comércio Varejista (Capital) & 4 & 14.81 \\
\hline Federação das Indústrias do Estado de Minas Gerais (FIEMG) (Capital) & 4 & 14.81 \\
\hline Secretaria de Atividades Urbanas (SAL) (Burocracia Municipal) & 4 & 14.81 \\
\hline Associação Comercial de Juiz de Fora (ACJF) (Capital) & 3 & 11.11 \\
\hline Serviço Nacional de Aprendizagem Comercial (Senac) (Visitante) & 3 & 11.11 \\
\hline
\end{tabular}

\footnotetext{
${ }^{5}$ Assim como o Corecon, a Embrapa não é definida diretamente nas categorias.

${ }^{6}$ A Universidade Federal de Juiz de Fora não se enquadra diretamente nas categorias, a exemplo do Corecon e da Embrapa. O assento é ocupado pela Faculdade de Engenharia, cujo perfil não se distancia do Corecon. Ainda assim, a opção também foi pelo registro neutro.

${ }^{7}$ Esse órgão passou a ser órgão efetivo a partir de março de 2011.
} 
(conclusão)

\begin{tabular}{|c|c|c|}
\hline Órgão & Freq. & $\begin{array}{l}\text { \% de par- } \\
\text { ticipação } \\
\text { em relação } \\
\text { ao total de } \\
\text { reuniões }\end{array}$ \\
\hline $\begin{array}{l}\text { Sindicato da Indústria e Construção Civil de Juiz de Fora - }(\text { Sinduscon })^{8} \\
\text { (Visitante) }\end{array}$ & 3 & 11.11 \\
\hline JF Empregos (Visitante) & 2 & 7.41 \\
\hline Executivo Municipal (Visitante) & 2 & 7.41 \\
\hline Secretaria de Assistência Social (SAS) (Visitante) & 1 & 3.70 \\
\hline Diretor Almaviva do Brasil (Visitante) & 1 & 3.70 \\
\hline Conselhos dos Sindicatos Contabilistas (Visitante) & 1 & 3.70 \\
\hline Masci - Empresa Junior (Visitante) & 1 & 3.70 \\
\hline Campe - Empresa Júnior (Visitante) & 1 & 3.70 \\
\hline Consultoria Granbery - Empresa Júnior (Visitante) & 1 & 3.70 \\
\hline Gerente aeroporto regional (Visitante) & 1 & 3.70 \\
\hline Pantanal linhas aéreas (Visitante) & 1 & 3.70 \\
\hline TRIP - Empresa de aviação (Visitante) & 1 & 3.70 \\
\hline Representante do Programa Pró Jovem Urbano (Visitante) & 1 & 3.70 \\
\hline Junta Comercial do Estado de Minas Gerais (Jucemg) (Visitante) & 1 & 3.70 \\
\hline $\begin{array}{l}\text { Agência de promoção de investimento e comércio exterior de Minas Gerais } \\
\text { (INDI) (Visitante) }\end{array}$ & 1 & 3.70 \\
\hline Sindicato das Indústrias de Alimentação de Juiz de Fora (SIAJF) (Visitante) & 1 & 3.70 \\
\hline Unitec Educacional (Visitante) & 1 & 3.70 \\
\hline Representante Trabalhadores (Visitante) & 1 & 3.70 \\
\hline Executivo estadual (Visitante) & 1 & 3.70 \\
\hline IFET (Visitante) & 1 & 3.70 \\
\hline Conselho Federal de Economia (Visitante) & 1 & 3.70 \\
\hline Instituto de Desenvolvimento em Vendas e Atendimento (IDEVA) (Visitante) & 1 & 3.70 \\
\hline Secretaria de Trabalho e Emprego (STE) (Visitante) & 1 & 3.70 \\
\hline Ecaderno (site ligado à educação) (Visitante) & 1 & 3.70 \\
\hline Agência de Gestão Ambiental de Juiz de Fora (Burocracia Municipal) ${ }^{9}$ & 0 & 0.00 \\
\hline
\end{tabular}

\footnotetext{
${ }^{8}$ Nas atas, esse órgão está colocado como membro, porém não foi possível encontrar seu nome entre os membros iniciais dispostos no decreto que regulamenta o Conselho, restando, assim, um impasse em relação a sua real posição. ${ }^{9}$ Esse órgão foi adicionado ao Conselho como membro, de acordo com o Decreto n. 10.617, de 2011, porém não se registrou sua presença em qualquer reunião no decorrer da análise das atas (JUIZ DE FORA, 2011).
} 
Chama a atenção que a partir dos 10 mais frequentes, e considerando a composição da presidência, não é difícil identificar a forte presença direta e indireta dos interesses da pequena burguesia em suas variadas expressões. Considerando, então, a presidência e a Secretaria de Planejamento e Desenvolvimento Econômico (que subsidia a presidência do Conselho), tem-se pelo menos seis dos 10 mais frequentes com orientações às pautas da pequena burguesia (Abrasel, Sebrae, CDL Juiz de Fora, Região Convention \& Visitors Bureau, Agência de Desenvolvimento de Juiz de Fora e Região e Centro Industrial de Juiz de Fora). Nas atas avaliadas, no entanto, não houve a devida numeração dos partícipes de cada reunião. Desse modo, foi possível compreender somente aqueles que assinaram no local correspondente ao órgão de que fazem parte, gerando, assim, alguns problemas, como a identificação de apenas um ou dois presentes em algumas das atas, mesmo sabendo que ao menos o quórum mínimo para a realização da reunião havia sido atingido.

Fica claro, pela análise das frequências, que entre os participantes do Conselho em tela, os mais frequentes são aqueles ligados às várias frações do capital e à pequena burguesia, e isso também acontece entre os participantes visitantes (que registra apenas um único convite a representante dos trabalhadores). Essa concentração na ocupação dos lugares é elementar, pois terá ressonâncias nos temas debatidos e demandas que aparecem nos encontros e, certamente, reforçará o poderio do capital perante a burocracia; ela própria já é intimamente inclinada em razão, também, da inteira ausência do contraditório no Conselho.

Assim, em relação aos temas mais debatidos, o problema do desenvolvimento é sempre parametrizado com o aperfeiçoamento das empresas no município. O que deve ser feito para que o desenvolvimento se efetive é explorar os aspectos que permitam às empresas evoluírem, como apresentado nos objetivos do Conselho. Prevalecem, nesse espaço de debate, os objetivos do empresariado, que argumenta dizendo que seu desenvolvimento tem como contrapartida a geração de emprego para os trabalhadores. Nesse sentido, um dos conselheiros afirma

\footnotetext{
Que o andamento das ações de desenvolvimento hoje superaram [sic] todas as suas expectativas e que com o apoio de todas as entidades empresariais, do Governo do Estado, do Instituto de Desenvolvimento Integrado de Minas Gerais INDI, junto à Secretaria de Desenvolvimento Econômico, estão vindo para Juiz de Fora quatro empresas com mais de trezentos empregos cada. (CONSELHO MUNICIPAL DE DESENVOLVIMENTO ECONÔMICO, 2010b).
} 
Evidentemente, é certo também que a profusa geração de empregos só pode ser alcançada quando a única possibilidade de desenvolvimento posta no horizonte é a que privilegia o capital, desconsiderando alternativas outras como, à guisa de exemplo, cooperativas populares. Em consonância com os objetivos do capital, tem-se que o “modelo de desenvolvimento adotado pela Prefeitura que está estruturado a partir de um tripé onde os elementos fundamentais são: a logística do município, a questão da inovação da indústria tecnológica, e a capacitação.” (CONSELHO MUNICIPAL DE DESENVOLVIMENTO ECONÔMICO, 2011c). O primeiro desses pontos foi observado em discussões que envolveram empresas aéreas e partícipes do Conselho que tratavam acerca da atividade do Aeroporto Regional da cidade, uma vez que sua atividade se realiza majoritariamente com viagens de empresários para grandes centros (CONSELHO MUNICIPAL DE DESENVOLVIMENTO ECONÔMICO, 2010a). Os outros dois pontos se amalgamaram a outros, como a pressão para a redução da carga tributária, sobretudo para atrair novas empresas para a cidade, e se consolidaram como as principais reivindicações.

Com respeito ao ponto da qualificação, um dos conselheiros comenta "que quando uma empresa maior quer investir, por exemplo, R\$ 100.000.000,00 no nosso município, eles são muito cautelosos, e procuram saber sobre a qualidade da mão-de-obra local.” (CONSELHO MUNICIPAL DE DESENVOLVIMENTO ECONÔMICO, 2011a). É, assim, colocado peso sobre essa questão da qualificação por ser elemento decisivo na atração de investimentos de empresas para a cidade. Também se pode ver o incentivo à disseminação dos próprios programas da Prefeitura em parceria com instituições como as do "Sistema S", que objetivam a formação de mão de obra com programas como:

\footnotetext{
Pró-Jovem Urbano, aumento da escolaridade com qualificação, com duração de dezoito meses e o Pró-Jovem Trabalhador que capacita diretamente para o mercado com duração de seis meses. Os projetos acontecem através de contratos com o Senac e o Senai, adequando aos pacotes oferecidos por eles. (CONSELHO MUNICIPAL DE DESENVOLVIMENTO ECONÔMICO, 2010a).
}

Na tentativa de aproximar essas instituições, um dos conselheiros "sugere que se convide também o SESI, SENAI e outras instituições de treinamento para participarem do Conselho.” (CONSELHO MUNICIPAL DE DESENVOLVIMENTO ECONÔMICO, 2011a). O que somou, assim, mais elementos ligados ao empresariado ao Conselho. Em um momento posterior, quando a temática da qualificação da mão de 
obra abre a possibilidade de participação de sindicatos de trabalhadores, por exemplo, em um debate acerca de um site para reunião de vagas de empregos e cadastro de currículos de trabalhadores, lê-se que "será feito também um trabalho com os sindicatos Patronais e dos Empregados para buscarem qual a demanda necessária dentro do mercado de Juiz de Fora, onde se possa retratar essa realidade nacional.” (CONSELHO MUNICIPAL DE DESENVOLVIMENTO ECONÔMICO, 2012d). Vê-se, portanto, que é meramente uma consulta posterior ao já debatido, visando a ratificar o que já fora proposto, nesse caso. Assim, as entidades de classe são convocadas a contribuir para uma melhor alimentação desse site, o que implica a superação do debate antes mesmo que ele aconteça. Não é colocado em perspectiva o questionamento dos aspectos inerentes ao site, somente as formas de fazê-lo funcionar. Esse site, em verdade, teve como importante mediação na sua elaboração a Secretaria de Assistência Social (CONSELHO MUNICIPAL DE DESENVOLVIMENTO ECONÔMICO, 2012c), articulando-se uma ferramenta para a prospecção de mão de obra. No avanço das discussões, a supracitada Secretaria se destaca, inclusive, como elemento da burocracia mais atuante no Conselho e mais próxima às demandas do capital, especialmente no que tange à qualificação dos trabalhadores a despeito da primeira impressão proporcionada pelo nome que carrega. Além da participação na criação do site, tal Secretaria coordena programas de qualificação. A título de exemplo, é possível acompanhar que

O Pró-Jovem Urbano visa: escolaridade/qualificação/cidadania com o objetivo maior em emprego e renda. [...] A Secretaria de Assistência Social faz o trabalho de capacitação dos jovens, a demanda do mercado de trabalho existe, é preciso fazer com que estas duas pontas se entrosem. (CONSELHO MUNICIPAL DE DESENVOLVIMENTO ECONÔMICO, 2010a).

Por mais que a qualificação, ressalte-se, possa trazer benefícios para os trabalhadores, sobretudo aqueles pertencentes a camadas mais baixas, privados de oportunidades, contribuindo para sua subsistência mínima, isso tem por finalidade colocar o jovem em condições de concorrência com outras forças de trabalho disponíveis. Quer dizer, a qualificação não é um fim em si mesma, mas mediação necessária às finalidades do capital e não é garantia diante das inconstâncias dos ciclos de crescimento e de baixa da economia.

Diversos setores da burguesia local são assim contemplados, marcando a função do Conselho no movimento da economia no Município. A burocracia municipal como uma mediação para a qualificação dos trabalhadores acontece por intermédio do 
apoio direto, como parcerias com instituições de formação ligadas ao capital, criação de ferramentas e pesquisas acerca do tema e banco de dados com mão de obra ociosa. Percebe-se, também, o engajamento prático da Secretaria de Assistência Social que lidera as principais iniciativas advindas do poder público municipal para contentar os anseios burgueses.

Outro ponto bastante presente nas atas é o desenvolvimento das pequenas e médias empresas. Isso acontece, por exemplo, com o incentivo para que sejam efetivadas, no município, leis que tragam vantagens para esse tipo de negócio, ligado ao pequeno capital, que, como visto, corresponde à grande parte dos estabelecimentos comerciais da cidade. Uma lei, que simplificava os procedimentos para a formação de microempresas na cidade, foi lembrada em uma das discussões em um momento em que estava em vias de ser aprovada na Câmara Municipal (CONSELHO MUNICIPAL DE DESENVOLVIMENTO ECONÔMICO, 2010a). Em outro momento, após o diagnóstico de que era necessário impulsionar a qualidade e a produtividade dessas empresas, "pensou-se na montagem de APL's ou clusters.”" (CONSELHO MUNICIPAL DE DESENVOLVIMENTO ECONÔMICO, 2010d). A partir dessa alternativa, foi mostrado um estudo feito por uma consultoria que apresentava os caminhos que esses modelos poderiam seguir para ser implementados.

De forma similar, pode-se compreender o apoio a empresas de médio porte, ou qualquer empresa que se mostrasse interessada em se mudar para Juiz de Fora. Um conselheiro informou “que a Secretaria da Fazenda da Prefeitura de Juiz de Fora está se mobilizando para tentar baixar a alíquota de ISS do município, para que o mesmo se torne competitivo para a vinda de empresas de Call Center.” (CONSELHO MUNICIPAL DE DESENVOLVIMENTO ECONÔMICO, 2010d). Por um lado, essa pressão mostra a coerência do Conselho com uma tendência histórica da Cidade, considerando a grande parcela de contribuição do setor de serviços para o PIB, como apontado anteriormente. Por outro, à medida que o desenvolvimento do capital era posto como única força motriz para o desenvolvimento da Cidade, as demandas desse capital perante a Prefeitura surgiam de forma cada vez mais variada e eram facilmente absorvidas. Ademais, os esforços são sempre para que essas empresas permaneçam na Cidade para comportar a mão de obra, pois se entende isso, logicamente, como o benefício da empresa para a população. E isso é aceito de maneira acrítica, sem se sopesarem as implicações dessa empregabilidade para os trabalhadores, suas condições, ou mesmo duração.

\footnotetext{
${ }^{10}$ Esses são aglomerados produtivos que reúnem empresas de determinado segmento em um espaço para que ali se desenvolvam. Nas atas, essa ideia também foi colocada como uma demanda do empresariado ante a prefeitura: “a parcela de contribuição pleiteada na Prefeitura de Juiz de Fora, como ponto de partida para a implantação dos aglomerados é a disponibilização de um terreno de 100.000 m2 (cem mil metros quadrados) de área útil.” (CONSELHO MUNICIPAL DE DESENVOLVIMENTO ECONÔMICO, 2010c).
} 
Em outro momento, não é possível dizer se se trata da mesma empresa citada, mas se percebe que a atração de novos investimentos por intermédio de incentivos fiscais era anunciada de maneira otimista no Conselho, exaltando-se a contrapartida da geração de empregos como o ganho considerável:

Destacou a importância da aprovação, em dezembro de 2010, da Lei que permite ao município reduzir a alíquota do ISS que incide sobre as atividades do setor de $5 \%$ para $2 \%$, igualando assim as condições tributárias locais às de outras cidades do país como Goiânia, Uberaba, etc. Da mesma forma, diante dessa iniciativa da Prefeitura de Juiz de Fora, a Brasil Center retomou suas atividades no município, empregando quase 1.800 pessoas em sua Unidade. (CONSELHO MUNICIPAL DE DESENVOLVIMENTO ECONÔMICO, 2011b).

Chama ainda mais a atenção, nesse caso, a postura propositiva do capital (em sua fração claramente comercial), que contrasta com a aceitação passiva da burocracia, destacando ainda mais posicionamento hegemônico do primeiro no Conselho em tela.

A despeito disso, havia, em relação à atratividade para novas empresas, algumas dificuldades sentidas pelos integrantes do Conselho e que adquiriram espaço no debate. Diante desses empecilhos, a tentativa de atrair novos negócios para a Cidade não fica somente nos incentivos fiscais, mas na própria intervenção municipal para facilitar a aquisição de terrenos para as instalações. Nessa direção, pode-se ler que:

O [Conselheiro 1] esclarece que o projeto da Fiat ainda está sendo trabalhado para ser negociado a desapropriação da área de $180.000 \mathrm{~m} 2$ com recursos do Estado, onde será construído um Centro de Distribuição de importação de carros, peças e equipamentos, onde, a mesma irá trabalhar junto com a Chrysler. Será uma área de grande operação comercial na entrada da cidade, da Zona da Mata, gerando assim, o ICMS para cidade. $\mathrm{O}$ [Conselheiro 1] explicou que trata-se [sic] de um projeto com pouca empregabilidade, em torno de 80 a 90 empregos, mas, com uma grande capacidade de geração de receita e de aumento de Pib para a cidade (CONSELHO MUNICIPAL DE DESENVOLVIMENTO ECONÔMICO, 2012a).

Nesse momento, surge também a possibilidade de fomento do capital produtivo, mantendo a coerência com a configuração dos empreendimentos na história recente de Juiz de Fora, considerando que o setor automotivo é um dos mais relevantes. Cabe, 
ainda, destacar que, anteriormente, a carga tributária, considerada alta, era colocada como obstáculo para a entrada de novas empresas na Cidade. Agora, a arrecadação passa a ser o argumento que fundamenta o pedido da intervenção do poder público para a aquisição do espaço pela empresa, posto que não haverá a geração de tantos empregos. Isso mostra que o melhor argumento é o mais conveniente com a situação do momento. Não se pode exigir, evidentemente, qualquer rigor acerca da coerência da elaboração dos argumentos da classe que se faz dominar nesse Conselho. Evidentemente, o poder econômico por ela exercido já é suficiente para conquistar suas demandas.

Fundamentalmente, as principais frações do capital são contempladas nas discussões do Conselho, sem que se reflita, aqui, a supremacia exercida pelo capital comercial na economia municipal. Destaca-se, nesse espaço, a pequena burguesia, mas sem obstruir os anseios de outras frações do capital.

Segue-se que, na discussão do plano plurianual da Cidade, também ficou claro como dominam em sua elaboração os interesses da burguesia local, pois o “objetivo estratégico é fomentar o desenvolvimento econômico local. A primeira ação é Atração de Empreendimentos Intensivos em Tecnologia e Setores Tradicionais e Melhoria do Ambiente de Negócios.” (CONSELHO MUNICIPAL DE DESENVOLVIMENTO ECONÔMICO, 2013). Outro instrumento de apoio ao capital, e por este requisitado frequentemente nas reuniões, foi a realização de eventos com o apoio da Prefeitura. Em maio de 2011, foi realizado, com o apoio da prefeitura, um evento “em parceria com o SEBRAE chamado Fomenta Minas, onde será realizado também o Fórum Local de Micro e Pequenas Empresas, [...] destinado a criar a Rede de Inovação da Zona da Mata Mineira, ambos projetos a serem apoiados pelo Fundo de Desenvolvimento Econômico.”11 (CONSELHO MUNICIPAL DE DESENVOLVIMENTO ECONÔ-

\footnotetext{
${ }^{11}$ Esse fundo foi instituído por lei municipal em 2010, tendo como principais fontes de recursos: "I - dotação consignada no orçamento do Município; II - resultado operacional próprio; III - contribuições do setor público e privado; IV - recursos de outras origens, repassados por órgão ou entidades nacionais ou estrangeiros [...]” (JUIZ DE FORA, 2010b). A Secretaria de Planejamento e Desenvolvimento Econômico se encarregaria de sua gestão assistida pelo Conselho em pauta (Juiz de Fora, 2010b). Não há, contudo, informações sobre prestação de contas exclusiva, a não ser o total gasto no ano, sempre próximo ao limite de $\mathrm{R} \$ 100.000,00$. Os objetivos do fundo são "I - fomento às atividades de prospecção de novos negócios capazes de atrair para o município investimentos diretos; II - produção de materiais institucionais que divulguem as vantagens competitivas que o Município oferece, bem como sua veiculação em canais de comunicação que possam atingir todo o território nacional; III - aquisição e desapropriação de áreas que serão destinadas a receber investimentos produtivos, podendo ou não ser organizados em distritos industriais; IV - estudos econômicos destinados à promoção e ao fortalecimento da cadeia produtiva de Juiz de Fora.” (JUIZ DE FORA, 2010b). Pode-se acompanhar, nas discussões, que esses objetivos são alinhados à utilização do Fundo pelo Conselho não obstante o fato de que a maioria de tais objetivos demandaria recursos em volume muito superior.
} 
MICO, 2011b). Do fim do ano 2011 em diante, o número de eventos empresariais apoiados pela prefeitura aumentou consideravelmente. Dentre eles, o IV Fórum Empresarial de Juiz de Fora (CONSELHO MUNICIPAL DE DESENVOLVIMENTO ECONÔMICO, 2011d), o Encontro Internacional de Desenvolvimento Sustentável, que buscou aliar diversas frações do capital em torno das tendências de desenvolvimento sustentável e também foi financiado pela Prefeitura (CONSELHO MUNICIPAL DE DESENVOLVIMENTO ECONÔMICO, 2012b), eventos no setor de turismo (CONSELHO MUNICIPAL DE DESENVOLVIMENTO ECONÔMICO, 2012e) e da indústria, com o Evento da Semana Industrial (CONSELHO MUNICIPAL DE DESENVOLVIMENTO ECONÔMICO, 2012b) que seguiu a mesma lógica dos outros eventos, recebendo também o apoio da Prefeitura. Esses eventos, além de sintetizarem claramente aqueles objetivos iniciais do Conselho, inclusive em relação à exploração do turismo e ao incentivo à inovação, sintetizam também a proximidade entre setores do capital local, a pequena burguesia e a Prefeitura, tônica desse espaço de debates.

A partir dessas questões, é possível considerar aspectos decisivos e que ajudam a dar resolução às hipóteses de trabalho antes consideradas. Primeiramente, dada a composição da presidência no período, é possível dizer que a pequena burguesia é a classe dirigente no Conselho. Mais especificamente, trata-se de uma combinação da velha e nova pequena burguesia. Para além disso, destacaram-se demandas como a diminuição dos impostos, a qualificação da mão de obra e o desenvolvimento das pequenas empresas as quais geraram o engajamento de conselheiros ligados à burocracia municipal, como a Secretaria de Assistência Social, e encetaram várias respostas da Prefeitura de modo a atendê-las. Em verdade, dos elementos da burocracia que participam dessa instância de debates, poucos são os que participam ativamente. A maioria praticamente se faz presente concordando com as posições do capital, ou estreitando o canal de comunicação entre este e a Prefeitura, por exemplo. As pequenas empresas, em especial, são os estratos mais próximos daquilo que se delimitou por pequena burguesia, nada inclinada às camadas proletárias. Tudo indica, também, que não há ocorrência de conflitos entre os setores da burguesia, que se manteve fortalecida e influente em todas as pautas colocadas. A falta de participação dos trabalhadores, ocasionada sobretudo pela falta de abertura, chamou a atenção, pois não ocorreu, mesmo nos momentos que tocavam esses trabalhadores de forma mais direta (sempre subsumidos como “capital humano”), como nos debates sobre qualificação. 


\section{DISCUSSÃO SOBRE AS HIPÓTESES DE TRABALHO}

Por tudo isso, é possível dizer que não há elementos para confirmar a primeira hipótese de trabalho. A posição da presidência no período é aderente à pequena burguesia não somente por sua composição e frequência às reuniões, mas também pela orientação nas pautas. O fato de se localizarem na burocracia municipal não engendra uma posição social distinta em relação às classes sociais.

Seguindo a ordem, não foi possível conferir uma supremacia ao capital comercial, como apontava a segunda hipótese. As orientações no geral vão na direção tanto de benefícios ao capital produtivo e comercial quanto, mais importante, às pequenas empresas. Nesse sentido, a realidade do Conselho denota uma supremacia da pequena burguesia, seja na composição, seja na orientação geral das atividades e aportes de recursos do Fundo de Desenvolvimento Econômico.

A terceira hipótese de trabalho não tem, igualmente, respaldo pelas análises, pois os trabalhadores não constituem de forma alguma o Conselho; são deles excluídos. É até possível dizer que uma condição para participar do Conselho é não ser trabalhador nem representante deste.

No sentido aludido antes a respeito da supremacia da pequena burguesia, a quarta hipótese de trabalho é parcialmente corroborada em razão da ausência de conflito entre as classes no interior do Conselho. Não há uma divisão exata da supremacia, mas é possível dizer que o Conselho se constitui como órgão dos interesses comuns dos setores do capital e da pequena burguesia com a direção política desta. As diferentes frações do capital articulam uma acomodação de interesses em que todas são contempladas.

Por último, mas não menos importante, a quinta hipótese de trabalho demonstra como a teoria a respeito dessas relações entre burocracia municipal e classes sociais não deve ignorar as particularidades concretas. Os presidentes do Conselho em pauta não se aliam à supremacia comercial (já que é inexistente) e nem à supremacia existente da pequena burguesia; eles são a própria pequena burguesia na direção do Conselho por serem alçados politicamente à posição de vértice da burocracia municipal em pauta.

Assim, uma primeira questão a ser considerada a partir dos achados é a incompatibilidade entre o tripé apriorístico Estado-mercado-sociedade civil e a reali-

\footnotetext{
${ }^{12}$ Com base nos dados do IBGE sobre o PIB e Salários e Outras Remunerações para o período entre 2008 e 2014, é possível constatar variação positiva de ambos os indicadores, em que o segundo vai de 20,77 a 24,76\% do primeiro. Mas não há registros dos lucros para efeito de comparação nem especificação para o Outras Remunerações.
} 
dade concreta. Para além do próprio caráter abstrato em, por exemplo, uma separação apenas intelectual entre mercado e sociedade - em si mesmos termos muito abstratos -, a análise do caso do Conselho em questão alude para o fato de que o parâmetro do Estado (seja que nível for) não é o de uma posição inteiramente ou sempre distinta das classes sociais. Essa questão, que precisa ser considerada de modo mais dedicado, obstrui não apenas as posições teóricas hegemônicas no “campo de públicas”, mas também a de Engels, por exemplo, quando supôs uma autonomização tal que garantia, por princípio, uma posição diferenciada. É mais correspondente ao movimento da realidade que tal possibilidade, seja ou não uma tendência, somente se efetive em contingências históricas. Não é o caso do Conselho no período estudado, pois fica evidente que não é uma posição diferenciada, precisamente em razão da supremacia da pequena burguesia como classe dirigente das pautas comuns aos interesses do capital.

Como não há uma posição diferenciada em relação às classes, é absolutamente impreciso ventilar uma aliança da burocracia com as frações do capital e a pequena burguesia. A realidade é melhor revelada pela constituição do Conselho como mediação para os interesses comuns, para efetivar a aliança entre os capitais e a pequena burguesia. A ausência do contraditório é exemplar, pois, como visto, os interesses das frações das classes trabalhadoras são subsumidos aos interesses dos capitais. O trabalho aparece sempre de modo passivo, como emprego, renda, “capital humano”. A assistência social, única naquele contexto capaz de exercer alguma contestação dos gastos, das pautas, da acriticidade, etc., é visitante convidado a funcionar como mediação aos interesses da própria aliança sob direção da pequena burguesia quando a matéria é a qualificação do trabalho. Nesse sentido, não é mera inclinação da burocracia aos interesses do capital em desfavor dos trabalhadores. A burocracia não é distinta, no caso, da pequena burguesia; está, sim, em aliança com as demais frações do capital.

Do mesmo modo, foi possível constatar que no caso em questão não se reflete certo constructo mais ou menos esquemático que congela a composição de classe da burocracia. Isso significa, também, que é imprudente utilizar esquemas transpostos para a análise da municipalidade como se esta fosse um microcosmo do que se passa no plano do Estado em nível nacional. Se para Poulantzas (1978), como apresentado anteriormente, é a burguesia que ocupa o vértice e a pequena burguesia as posições mais baixas da burocracia -, o caso concreto revelou, em verdade, que é a pequena burguesia que dirige a posição da presidência do Conselho e, por pressuposto, a secretaria correlata. É uma questão de saber se o achado é válido apenas para o período em questão, somando-se às limitações da presente pesquisa. 
Essa última questão aponta para a dificuldade em relação a dados econômicos que pudessem melhorar a precisão da hipótese sobre a supremacia do capital comercial. Dada a participação no PIB e nas receitas correntes, tratou-se o capital comercial inicialmente como um bloco mais geral e que engloba os pequenos comerciantes. Não há, até agora, dados econômicos desagregados sobre a participação dos diferentes tipos de empresa, o que permitiria distinguir o peso do capital comercial perante a pequena burguesia que extrai lucro também da circulação como sua contraparte mais concentrada. Na mesma direção, não há registros estatísticos para determinar como a riqueza produzida na cidade é dividida entre lucros e salários. ${ }^{12}$

Não obstante, os dados são consideravelmente consistentes para o período analisado. O levantamento dos dados econômicos ajuda a dar conteúdo e contexto às classes sociais no Município e permitem explicitar o nexo entre a economia e a burocracia municipal precisamente por mediação do Conselho. Com isso, evita-se, aqui, a tendência dominante na administração pública que obscurece aquilo que a explica.

\section{CONSIDERAÇÕES FINAIS}

Com esta pesquisa, procurou-se investigar a relação da burocracia com as classes sociais nos debates do Conselho Municipal de Desenvolvimento Econômico de Juiz de Fora. Para a concreção deste trabalho, foi fundamental posicionar a burocracia não como classe, mas como um elemento que mesmo não estando ligado de forma imediata às relações de produção, não está isolado delas e pode influir nas relações de classe por intermédio de alianças, por exemplo.

A despeito de limitações impostas pela investigação baseada sobretudo nas atas, pôde-se constatar que o Conselho compreende uma estreita relação entre a burocracia e os capitais locais. Esses últimos sendo representados majoritariamente pela fração comercial e pela pequena burguesia, principais expoentes econômicos da história recente da Cidade. Nos debates, destaca-se a supremacia da pequena burguesia, classe da qual fazem parte os presidentes e vice-presidentes do Conselho durante o período pesquisado, e que consegue viabilizar variadas demandas para seu desenvolvimento. Isso, contudo, ocorre com a coadunação de interesses das diferentes frações do capital, pois não se identificam no espaço de debate frações que ficam à margem das discussões. A aparente ausência do capital financeiro se explica por duas razões. Por um lado, faz-se presente indiretamente como mediador das operações de crédito e fluxo monetário na Cidade. Por outro, não aparece com muita influência direta pela 
ligação com aspectos federais os quais não se encontram em uma cidade do porte de Juiz de Fora.

Por fim, constatou-se o alinhamento da burocracia com o capital, mas em sentido especial. Além de aquela manter-se indiferente à não participação de trabalhadores no Conselho, concordou integralmente com os pontos colocados pelas frações da burguesia porque, em verdade, é parte da pequena burguesia em aliança com as frações do capital. Mais importante ainda, a participação da burocracia sempre ocorreu de maneira passiva, sem pautar debates, apenas referendando demandas. De modo que o setor mais ativo da burocracia (a Secretaria de Assistência Social) no Conselho sequer fazia parte como membro integrante, participando contingencialmente de reuniões quando sua presença era necessária.

Esta pesquisa, entretanto, limitada a um único conselho e em um período pouco extenso em razão da disponibilidade das atas, precisa ampliar o escopo e abarcar outros conselhos, além de implementar métodos diferenciados, como observação não participante. Não obstante suas limitações, contribui no sentido de lançar luz sobre aspectos consideravelmente negligenciados pela pesquisa corrente.

\section{REFERÊNCIAS}

ANDRADE, S. M. B. V. de. Classe operária em Juiz de Fora: uma história de lutas (1912-1924). Juiz de Fora: Eduf, 1987.

BELLUZZO, L. G. de M.; LIMA, L. A. de O. O capitalismo e os limites da burocracia. In: SODRÉ, N. W. Temas de Ciências Humanas. São Paulo: Ciências Humanas, 1978. v. 3.

BERNARDO, J. Gestores, Estado e Capitalismo de Estado. Revista Ensaio, Santo André, v. 14, 1985.

BRESSER-PEREIRA, L. C. A sociedade estatal e a tecnoburocracia. São Paulo: Brasiliense, 1982.

\section{CONSELHO MUNICIPAL DE DESENVOLVIMENTO ECONÔMICO. Ata da} reunião realizada no dia 13 de dezembro de 2012. Juiz de Fora, 2012a. Disponível em: <https://drive.google.com/file/d/0B-4BdQ0vnn_ZaTdFQ3REMlJVZVE/view>. Acesso em: 20 jul. 2017. 
CONSELHO MUNICIPAL DE DESENVOLVIMENTO ECONÔMICO. Ata da reunião realizada no dia 15 de setembro de 2010. Juiz de Fora, 2010a. Disponível em: <https://drive.google.com/file/d/0B-4BdQ0vnn_ZaHNkQUFHQTVPWkk/ view>. Acesso em: 20 jul. 2017.

CONSELHO MUNICIPAL DE DESENVOLVIMENTO ECONÔMICO. Ata da reunião realizada no dia 16 de março de 2012. Juiz de Fora, 2012b. Disponível em: <https://drive.google.com/file/d/0B-4BdQ0vnn_ZcHJZbXYtVzY5dUE/view>. Acesso em: 10 jul. 2017.

CONSELHO MUNICIPAL DE DESENVOLVIMENTO ECONÔMICO. Ata da reunião realizada no dia 17 de agosto de 2010. Juiz de Fora, 2010b. Disponível em: <https://drive.google.com/file/d/0B-4BdQ0vnn_ZRnZBTXRvUkFTTWc/view>. Acesso em: 20 jul. 2017.

CONSELHO MUNICIPAL DE DESENVOLVIMENTO ECONÔMICO. Ata da reunião realizada no dia 24 de fevereiro de 2011. Juiz de Fora, 2011a. Disponível em: <https://drive.google.com/file/d/0B-4BdQ0vnn_ZbEd2MUY0bHEyWWs/ view>. Acesso em: 20 jul. 2017.

CONSELHO MUNICIPAL DE DESENVOLVIMENTO ECONÔMICO. Ata da reunião realizada no dia 26 de maio de 2011. Juiz de Fora, 2011b. Disponível em: <https://drive.google.com/file/d/0B-4BdQ0vnn_ZRGJlMGIMa2tCVTg/view>. Acesso em: 20 jul. 2017.

CONSELHO MUNICIPAL DE DESENVOLVIMENTO ECONÔMICO. Ata da reunião realizada no dia 26 de outubro de 2010. Juiz de Fora, 2010c. Disponível em: <https://drive.google.com/file/d/0B-4BdQ0vnn_ZM2RqR0w1NGQ3cVk/view>. Acesso em: 20 jul. 2017.

CONSELHO MUNICIPAL DE DESENVOLVIMENTO ECONÔMICO. Ata da reunião realizada no dia 27 de abril de 2012. Juiz de Fora, 2012c. Disponível em: <https://drive.google.com/file/d/0B-4BdQ0vnn_ZQ0hIdFViNC1LV3M/view>. Acesso em: 20 jul. 2017.

CONSELHO MUNICIPAL DE DESENVOLVIMENTO ECONÔMICO. Ata da reunião realizada no dia 28 de abril de 2011. Juiz de Fora, 2011c. Disponível em: <https://drive.google.com/file/d/0B-4BdQ0vnn_ZNXVnQWFpbHM0UXc/view>. Acesso em: 20 jul. 2017. 
CONSELHO MUNICIPAL DE DESENVOLVIMENTO ECONÔMICO. Ata da reunião realizada no dia 28 de julho de 2012. Juiz de Fora, 2012d. Disponível em: <https://drive.google.com/file/d/0B-4BdQ0vnn_Za3ZiVHZsNnRaQlk/view>. Acesso em: 20 jul. 2017.

CONSELHO MUNICIPAL DE DESENVOLVIMENTO ECONÔMICO. Ata da reunião realizada no dia 28 de julho de 2013. Juiz de Fora, 2013. Disponível em: <https://drive.google.com/file/d/0B-4BdQ0vnn_ZaVVHazhaMEpTOVU/view>. Acesso em: 20 jul. 2017.

CONSELHO MUNICIPAL DE DESENVOLVIMENTO ECONÔMICO. Ata da reunião realizada no dia 29 de maio de 2012. Juiz de Fora, 2012e. Disponível em: <https://drive.google.com/file/d/0B-4BdQ0vnn_ZVE1HeU1ZMTFMM2s/view>. Acesso em: 20 jul. 2017.

CONSELHO MUNICIPAL DE DESENVOLVIMENTO ECONÔMICO. Ata da reunião realizada no dia 30 de setembro de2009. Juiz de Fora, 2011d. Disponível em: <https://drive.google.com/open?id=0B-4BdQ0vnn_ZdDl5c1JyRDhlcFk>. Acesso em: 20 jul. 2017.

CONSELHO MUNICIPAL DE DESENVOLVIMENTO ECONÔMICO. Ata da reunião realizada no dia 30 de novembro de 2010. Juiz de Fora, 2010d. Disponível em: <https://drive.google.com/file/d/0B-4BdQ0vnn_ZQ0UwektkNVhwZFk/ view>. Acesso em: 20 jul. 2017.

DEMO, P. Introdução à metodologia da ciência. São Paulo: Atlas, 1985.

ENGELS, F. Revolution and Counter-Revolution in Germany. In: Collected Works, v. 11. London: Lawrence \& Wishart, 2010.

GALBRAITH, J. K. O novo Estado industrial. São Paulo: Pioneira, 1983.

GURGEL, C.; JUSTEN, A. Controle social e políticas públicas: a experiência dos Conselhos Gestores. Revista de Administração Pública, v. 47, n. 2, 2013.

HIRATA, H. Capitalismo de estado, burguesia de estado e modo de produção tecnoburocrático. Revista Discurso, São Paulo, n. 12, 1980. Disponível em <http://www. revistas.usp.br/discurso/article/viewFile/37881/40608>. Acesso em: 20 jul. 2017.

IBGE. Cidades. Minas Gerais. Juiz de Fora. Disponível em: <http://cod.ibge.gov. br/7PF>. Acesso em: 20 jul. 2017. 
JUIZ DE FORA. Decreto n. 10.234, de 07 de maio de 2010. Altera o decreto 9704, de $1^{\circ}$ de dezembro de 2008, que aprova o regulamento do conselho de desenvolvimento econômico. Prefeitura de Juiz de Fora, 07 maio 2010. Disponível em: <https:// leismunicipais.com.br/a/mg/j/juiz-de-fora/decreto/2010/1024/10234/decreto-n-10234-2010-altera-o-decreto-9704-de-1-de-dezembro-de-2008-que-aprova-o-regulamento-do-conselho-de-desenvolvimento-economico>. Acesso em: 20 jul. 2017.

JUIZ DE FORA. Decreto n. 10.617, de 12 de janeiro de 2011. Altera o Decreto $\mathrm{n}^{\circ}$ 10.234, de 07 de maio de 2010, que aprova o Regulamento do Conselho de Desenvolvimento Econômico. Prefeitura de Juiz de Fora, 12 jan. 2011.

Disponível em: <http://www.jflegis.pjf.mg.gov.br/c_norma.php?chave $=0000033514>$. Acesso em: 20 jul. 2017.

JUIZ DE FORA. Lei n. 12.085, de 16 de julho de 2010. Diário Oficial Eletrônico, 17 jul. 2010. Disponível em: <https://www.pjf.mg.gov.br/e_atos/e_atos_vis. php?id=3647> . Acesso em: 20 jul. 2017.

MANDEL, E. Marx e Engels: a produção de mercadorias e a burocracia - as bases teóricas para a compreensão marxista da União Soviética. Revista Ensaio, São Paulo, 1985.

MARX, K.; ENGELS, F. Engels to Conrad Schmidt. In: MARX, K.; ENGELS, F. (Ed.). Collected Works. Letters 1890-92. London: Lawrence \& Wishart, 2010. v. 49.

MARX, K. Grundrisse. São Paulo: Boitempo, 2011.

MARX, K. O capital. Livro III. São Paulo: Boitempo, 2017.

MÉSZÁROS, I. Para além do capital. São Paulo: Boitempo, 2011.

OLIVEIRA, L. E. de. Os trabalhadores e a cidade: a formação do proletariado de Juiz de Fora e suas lutas por direitos (1877-1920). Juiz de Fora: Funalfa; Rio de Janeiro: FGV, 2010.

PAÇO CUNHA, E. Que fazer da burocracia de estado? Do indiferentismo às reciprocidades. Administração Pública e Gestão Social, v. 8, n. 1, p. 15-26, jan./mar. 2016.

POULANTZAS, N. As classes sociais no capitalismo de hoje. Rio de Janeiro: Zahar, 1978. 
PREFEITURA MUNICIPAL DE JUIZ DE FORA. PJF de portas abertas. Receitas Públicas. Receita Total do Município. Disponível em: <https://www.pjf.mg.gov.br/ transparencia/receitas/total/index.php>. Acesso em: 20 jul. 2017.

REZENDE, T. D. H. de. Da Legitimidade Democrática à Efetividade Social: análise do Conselho Administrativo de Recursos Fiscais-CARF. Sociedade em Debate, v. 22, n. 1, p. 141-174, 2016.

RIZZI, B. A burocratização do mundo. Lisboa: Antígona, 1983.

SOUZA FILHO, R.; GURGEL, C. Gestão Democrática e Serviço Social: princípios e propostas para a intervenção crítica. São Paulo: Cortez, 2016.

\title{
Agradecimento
}

Registre-se o agradecimento à Fundação de Amparo à Pesquisa do Estado de Minas Gerais (Fapemig) pelo financiamento do projeto de pesquisa que resultou no presente trabalho.

\section{Como citar este artigo:}

\begin{abstract}
ABNT
PAÇO CUNHA, Elcemir; GUEDES, Leandro Theodoro. Supremacia pequeno-burguesa no conselho municipal de desenvolvimento econômico de Juiz de Fora (2010 a 2014). RACE, Revista de Administração, Contabilidade e Economia, Joaçaba: Ed. Unoesc, p. 73-104, 2017. Edição Especial. Disponível em: <http://editora.unoesc.edu.br/index.php/race>. Acesso em: dia/mês/ano.

APA

Paço Cunha, E., \& Guedes, L. T. (2017). Supremacia pequeno-burguesa no conselho municipal de desenvolvimento econômico de Juiz de Fora (2010 a 2014) [E. especial]. RACE, Revista de Administração, Contabilidade e Economia, 73-104. Recuperado em dia/mês/ano, de http://editora.unoesc.edu.br/index.php/race
\end{abstract}


